\title{
Computer analysis of biographies to study family influence on the educational way of a person
}

\author{
Zoya Proshkova* \\ Sociological Institute of the Federal Center of Theoretical and Applied Sociology of the Russian \\ Academy of Sciences, 190005 Saint Petersburg, Russia
}

\begin{abstract}
The article presents the results of a computer analysis of biographical materials on the educational way of a person. In this sociological study, a collection of autobiographical essays of students of higher educational institutions was carried out. The received texts were processed using the Russian computer program Discant. Structuring, classification and digital codification of the content of biographical texts were used. As a result of the computer analysis, family factors that influence the development and implementation of the educational route of children were identified and described in detail. The sociological study resulted in a rating of effective ways of family support for children's education. It has been established that the most effective family factors for ensuring the educational way of children are the education of parents, the values of education and culture in the family, the parents' search for strong educational institutions and their willingness to invest in children's education. The findings indicate the need for individualization of modern educational routes and social support for families with children of school and preschool age. The methodological perspective of the project is to develop new methods for computer analysis of large amounts of biographical data.
\end{abstract}

\section{Introduction}

Qualitative and quantitative approach to analysis of biographic texts in sociology. Computer technologies for processing large amounts of quantitative sociological data have been around for a long time. The most popular program is SPSS (Statistical Package for the Social Sciences) [1]. The system allows you to study the results of representative surveys using a variety of techniques, as well as present the findings of empirical projects in tables, graphs, distributions [2]. Other types of sociological research, the so-called qualitative research, receive primary data, not similar to coding sheets and databases with digital information that can be easily processed. In biographical projects, sociologists analyze biographical essays written at the request or order of researchers [3]. Most often, a biographical approach uses such a method of collecting information as a biographical interview [4].

The result of biographical research is arrays of unstructured texts. Sociologists usually analyze them in traditional ways. Researchers carefully read the received stories, find the

\footnotetext{
${ }^{*}$ Corresponding author: eder57@yandex.ru
} 
most interesting topics, quote statements from biographies in order to confirm or confute the hypotheses put forward in the project. Texts of high importance for understanding the history and culture of a society are fully published. An example of the latter approach is the Housing History project, conducted by sociologists from St. Petersburg. The interviews collected in the research on how a person found housing in a big city were published in the book "My Housing History. Autobiographical essays and biographical interviews" [5]. In projects of this kind, the status of an informant is almost equal to the status of a researcher. Therefore, informants are given the opportunity to speak freely on the pages of published articles and books.

The question of how to use the advantages of a computer approach to the analysis of biographies arises in those cases when large arrays of texts are typed (from 50 or more). One of the popular domestic services that help to study significant amounts of textual information of biographical research is Disant. Discant is a text classification and analysis program, created by Russian scientists G.I. Saganenko and E.K. Kanevsky [6]. The program allows you to work with different types of unstructured information. The program is most suitable for analyzing answers to open questions in the questionnaire. A striking example of Discant application to the study of questionnaire results based on open questions is the research of A.E. Heger "Value orientations of Russian youth" [7]. Using this program, the sociologist was able to compile and substantiate a list of values and propose several of their ratings according to various criteria. It is more difficult to work with biographical essays and interviews, but Disant is able to cope with long texts due to the qualitative-and-quantitative analytical approach. The program provides the opportunity to give a total assessment of written and oral statements of various informants, to highlight thematic keynotes important for the researcher. Discant allows you to use several methods of structuring texts; the classification of text fragments is especially effective.

The objective of the study presented in this article is to analyze with the use of Disant computer program a large array of biographical essays on the educational way of a person, starting from preschool age. We were interested in the influence of the family and the immediate environment on the development and implementation of educational routes for children. It is necessary to evaluate the family factor in the educational way of a person, since it is the parents of the schoolchildren and students who, along with teachers, are one of the main subjects of the educational process.

Another objective of a sociological project is to analyze the relevance of computer technology in application to significant volumes of unstructured primary data in sociological studies of qualitative type.

\section{Research methodology}

\section{Biographic essays "my educational way".}

Texts about the educational trajectory of a man have been collected since 2006. Data collection method is a request to informants to write an essay in a free form, talking about their education and profession. The authors of the essays were students of St. Petersburg State University and St. Petersburg State Institute of Culture. Full-time students prevailed, but there are texts from part-time students as well.

We did not limit the volume and method of writing essays, but for simplicity of completing the task, we offered the informants a plan, which had the questions we were interested in. We asked students to tell whether they went to kindergarten, for how long, what knowledge they managed to learn while preparing for school. The largest block of questions was referred to as schooling. For example, the participation of parents in entering the school, 
the help of family in preparing lessons, any experience with a tutor and in hobby clubs, paid and free tuition at school age, the reasons for the change of school.

So, with the help of collecting biographical essays, it was possible to discover and describe such an educational way that is becoming popular as a transition in high school to an online school [8]. It turned out that students in grades 8-9, together with their parents, strive to individualize the educational way in order to better prepare for the unified state exam and go to university [9]. Online schools offer to focus on the subjects necessary for students and test out a number of compulsory subjects in the school curriculum. In addition, studying in online schools allows you to better master digital educational technologies and save time and health of students.

The block of school questions ended with a request to assess the comfort of the school educational environment and talk about conflicts with teachers, classmates, parents. The next thematic block referred to enter college or university after grade 9 or 11 . We asked about professional plans, parental investments in admission to the chosen educational institution. The guidebook with questions helped not only the authors of the essays, but also the researchers. Sociological analysis, including the use of computer technology, is easier to do with minimal structuring of texts and some ready-made assessments of statements. The informants were distinguished by different degrees of reflexivity, so the shortest essays were written in two pages, most texts reached 5-6 pages, some prepared long essays of 10-12 pages.

The total number of essays is 114; for the analysis of parental influence we selected 100 texts. The fact is that not in all works the theme of a family arose, which was directly interested by the researchers. Several students talked about their studies in kindergarten, school and university as if education from an early age was their own business. It can be assumed that either the participation of parents in the educational life of children was almost absent, or the author of the essay did not realize the degree of influence of the family on his educational past and educational choice. We were not able to conduct an interview with these students, so the question remained open.

After editing the essays in a text editor, the database structure in Disant was developed, consisting of 18 fields of various types in accordance with the research questions:

1. Kindergarten, learning experience (1-yes, 2-no, 3-not mentioned).

2. Assessment of kindergarten (1-positive, 2-negative, 3-neutral).

3. Assessment of school (1-positive, 2-negative, 3-neutral).

4. School: school subjects.

5. School: homework.

6. Change of school, reasons for changing the school route.

7. School: teachers.

8. School: conflicts.

9. School: preparing for college and university.

10. Extracurricular education: clubs, sections, tutors.

11. Secondary specialized education (1-yes, 2-no).

12. Work experience (1-yes, 2-no).

13. Profession, specialty.

14. Education of parents, participation of parents in educational way.

15. Nickname.

16. Sex (1 female, 2 male).

17. Age.

18. Reserve field.

To analyze the parental support of the educational way of a person at preschool and school, as well as in the first years of study at a college or university, a special field was added. The role of the family became actual in several subjects, for example, a story about 
conflicts at school or tutors. Assessment of parental influence on the educational way was either described by an informant in the "family" section, or mentions of parents were scattered throughout the text. The first case is easier for processing essays in Discant. In the second case, the researcher had to collect fragments of the text and recreate a complete story about the family.

A computer analysis of stories about parental participation in a child's education made it possible to classify the main topics raised by students. Firstly, informants always reported on the education of the parents and, in some cases, of the grandmothers and grandfathers. With the same enthusiasm, students talked about the educational experience of their brothers and sisters, comparing their successes with their own achievements. Secondly, if we talk about the educational spheres mentioned in relation to parents, the school had become the leader. Not everyone reported about kindergartens and other types of preschool education, and informants considered admission to the university to be their personal strategy, supported by the parents. When classifying the content of texts, we relied on criteria such as the frequency of statements on a topic and a general assessment of an event or situation.

\section{Results of the study}

Classification of family influence factors on the educational way.

An analysis of the most popular topics presented in the essays made it possible to find and name the leading factors of the influence of parents and immediate family on the development and implementation of the educational way of a person. It turned out that some of the factors are backing, that is, close to the conditions or circumstances of human life. Other factors appear in active actions of parents aimed to help their children enter a good educational institution, as well as do well in studies. The most significant family levers of influence on children were described in detail. This explains the process of family educational socialization.

Table 1. Factors of parents influence on the educational way in the assessment of informants.

\begin{tabular}{|c|c|c|c|c|}
\hline № & $\begin{array}{c}\text { Family } \\
\text { influence } \\
\text { factors }\end{array}$ & Main types of text messages & $\begin{array}{c}\text { Number of } \\
\text { assessment } \\
\text { s (+) }\end{array}$ & $\begin{array}{c}\text { Number of } \\
\text { assessments } \\
(-)\end{array}$ \\
\hline 1 & $\begin{array}{l}\text { Education of } \\
\text { parents }\end{array}$ & $\begin{array}{l}\text { Higher education (scientific degree) of } \\
\text { mother and father, higher education of } \\
\text { grandparents, higher education of } \\
\text { brothers and sisters, secondary } \\
\text { specialized education of parents. }\end{array}$ & 70 & 10 \\
\hline 2 & $\begin{array}{l}\text { Values of } \\
\text { education and } \\
\text { culture in } \\
\text { family }\end{array}$ & $\begin{array}{l}\text { A large library at home, read a lot in the } \\
\text { family, a precept for higher education } \\
\text { were formed in children, a family went to } \\
\text { performances, grandmother taught } \\
\text { languages, parents made lists of books } \\
\text { and films. }\end{array}$ & 68 & 0 \\
\hline 3 & $\begin{array}{c}\text { Entering an } \\
\text { educational } \\
\text { institution }\end{array}$ & $\begin{array}{l}\text { Applying for a speech therapy } \\
\text { kindergarten, finding a good teacher in } \\
\text { elementary school, getting into school, } \\
\text { helping to enter a high-ranking school, } \\
\text { choosing an online school, choosing a } \\
\text { college and university, finding tutors, } \\
\text { searching for courses for preparing for } \\
\text { final exams at school. }\end{array}$ & 62 & 11 \\
\hline
\end{tabular}


Continuation of table 1.

\begin{tabular}{|c|c|c|c|c|}
\hline 4 & $\begin{array}{c}\text { Tuition } \\
\text { payment }\end{array}$ & $\begin{array}{c}\text { Payment for classes in kindergarten, } \\
\text { payment for additional lessons at school, } \\
\text { payment for clubs and sections, payment } \\
\text { for classes with a tutor, payment for } \\
\text { excursions and theater performances, } \\
\text { payment for online courses, payment for } \\
\text { private schools, payment for tuition. }\end{array}$ & 51 & 6 \\
\hline 5 & $\begin{array}{c}\text { Help in doing } \\
\text { schoolwork }\end{array}$ & $\begin{array}{c}\text { Parents helped to complete school lessons } \\
\text { in elementary school, father helped with } \\
\text { mathematics throughout the school, } \\
\text { mother and grandmother checked } \\
\text { homework, mother prepared for annual } \\
\text { exams in a high-ranking school. }\end{array}$ & 32 & 15 \\
\hline 6 & $\begin{array}{c}\text { Profession of } \\
\text { parents }\end{array}$ & $\begin{array}{c}\text { One or both parents are teachers, } \\
\text { lecturers at a college or university; } \\
\text { professionally successful parents, parents } \\
\text { with good earnings. }\end{array}$ & 21 & 0 \\
\hline 7 & $\begin{array}{c}\text { Parent } \\
\text { involvement in } \\
\text { school } \\
\text { conflicts }\end{array}$ & $\begin{array}{c}\text { Parents helped in conflicts with teachers, } \\
\text { mother changed the school because of } \\
\text { bad relations with the class teacher, told } \\
\text { the mother about quarrels with } \\
\text { classmates, father insisted on transferring } \\
\text { to another group in English. }\end{array}$ & 19 & 7 \\
\hline 8 & $\begin{array}{c}\text { Search for } \\
\text { additional } \\
\text { education for } \\
\text { children }\end{array}$ & $\begin{array}{c}\text { Parents sent the child to a music school, } \\
\text { studying at an art school at the suggestion } \\
\text { of their parents, my mother took } \\
\text { choreography classes, my grandmother } \\
\text { signed me into a club. }\end{array}$ & 14 & 0 \\
\hline TOTAL: & $\begin{array}{c}386 \text { assessments in 100 essays } \\
\text { main }\end{array}$ & $337(+)$ & $49(-)$ \\
\hline
\end{tabular}

The main results of the study are shown in the table with the types of family support of the educational way of informants that are most often found in essays. Discant provided the classification of text fragments according to different groups of family factors of the educational way. The hierarchy of factors influencing parents on the educational track of children is built depending on the frequency of occurrence of a particular topic in essays.

In addition, we determined how, positively or negatively, the authors of the essays evaluated the participation of parents in the educational process. The computer program Disant suggests using mixed fields in such cases. Text is entered on one side of the field, and a code that assesses the content of the text can be entered on the other. For example: "Parents found me an excellent tutor in English from the first grade"/2 - a positive assessment. The statement belongs to the fourth group, "Tuition payment", and we believe that the author of the essay was positive about helping parents to learn a foreign language, so we assigned the statement the code "2" (the code "1" was entered into the field in case of a negative assessment of the action or situation). As a result of the analysis, researchers receive a list of textual statements and statistical indicators characterizing the totality of biographical essays.

It was not always possible to fairly determine the author's assessment of the family influence factors on the educational way presented in the essays. For ease of analysis, a dichotomous scale was introduced - a positive or negative attitude to the presented subjects. We had to disregard neutral or ambivalent assessments. As a result of the analysis of one hundred selected biographical texts, we got eight groups of family factors and 386 assessments (337 - positive, 49 - negative). 


\section{Discussing the results}

Parents influence factors on the educational route.

The authors of the essays understand that the family took part in the development and implementation of their educational route, and talk about the different evidence of such participation. Several informants believe that the role of family was minimal, most pay tribute to their family environment. The number of positive assessments of family influence exceeds the number of negative comments by almost seven times.

\section{1 "Education of parents"}

In the first place in the frequency of references was such a basic factor in family life, as the education of parents. Informants informed about diplomas of institutes, universities, and technical schools of their fathers and mothers. Higher education is always evaluated positively. Especially successful parents are considered to be candidates and doctors of science. Children strive either to surpass the educational achievements of their parents, or to correspond to the achieved family level. The conclusion about the importance of higher education of parents is confirmed by data from other sociological studies [10].

\section{2 "The values of education and culture in family"}

Family attitudes regarding the goals and values of education took the second place. They are closely related to the first group of factors, that is, the education of parents. This entails the attitude towards reading, cultural leisure, general development, and the profession. Parents do not need to have a higher education to form a desire in their children to graduate. In the essays there were parents with a college diploma that generated in their children the goal to receive higher education. According to the analysis of biographical texts, the values of education in a family are not exclusively a backing factor in the family influence on the educational way of a person. Such values, as a rule, turn into actions in relation to the child: supplying children with books, searching for additional education, creating an educational plan for children.

\section{3 "Entering an educational institution"}

This group includes biographical plots, which told about the efforts of parents to get their children in kindergarten, school and university. Ordinary kindergartens and schools were accessible to the authors of the texts, so it was a question of entering logopedic kindergartens and schools with in-depth teaching of subjects, specialized gymnasiums and lyceum, as well as high-ranking schools, included in the top "500 best schools in Russia." The choice of college and university was discussed by informants with their parents. The support of family consisted mainly in preparing schoolchildren for the successful passing of the general state exam (GSE) and the unified state exam (USE).

\section{4 "Tuition payment"}

The fourth place was taken by the monetary investments of parents in the education of the child. This is one of the most obvious factors of a family support in the educational way of children. In the fourth group we included payment for additional school lessons, clubs and sections, classes with a tutor. This also includes tuition at private schools, including online schools, and at commercial departments of universities. Negative assessments of the factor 
are associated with criticism of paid educational services, which, in the opinion of the authors of biographical essays, should be free of charge.

\section{5 "Help in doing schoolwork"}

One of the features of modern Russian school education is the need to help children with homework. This applies to primary grades, as well as secondary grades in high-ranking schools. This type of family support received the most critical reviews in essays. The informants would not want to participate so actively in the daily education of their children, but admit that they themselves would not have been able to cope with schoolwork without parental assistance.

\section{6 "Profession of parents"}

The sixth place was taken by such family support factor for the educational way of children as a professional activity of parents. Informants reported in the essays on the profession of father and mother if parents had a successful career, held leadership positions, were teachers at school or university professors. That is, children could rely on the professional status of their parents and/or use the knowledge of the family in their own studies. Informants, whose parents are less successful, report on them in a neutral way and do not connect their educational achievements with the professional background of the family.

\section{7 "Parent involvement in school conflicts"}

The collected biographies constantly have stories of school conflicts - with teachers and classmates. Clashes do not always require parental intervention, but the authors of essays describe such cases. Parents acted as active advocates for children. The most serious action on the part of the family was the change of school, as well as the fulfilled requirement to transfer the child to another class.

\section{8 "Search for additional education for children"}

The last place was taken by the actions of the family to provide the child with out-of-school education. These statements could be attributed to the third group, but we decided to put them separately. It is about finding sports and creative clubs for preschoolers and schoolchildren. Informants evaluate this family activity always positively and emotionally. The skills acquired in the system of additional training help in choosing a profession and strengthen the physical and mental health of students.

\subsection{The effectiveness of computer analysis of biographies}

Discant program could comprehensively study a large array of biographical texts and obtain summary assessments of the content of essays on the educational way. It is convenient to use the stored database of electronic data, it is possible to clarify the findings, delve into the analysis of relevant topics. The unstructured primary data of high-quality sociological projects require the systematic support of modern computer technologies. This provides a better understanding of sociological information. 


\section{Conclusions}

A sociological study revealed eight factors of family influence on the educational way of a person. The most powerful of them is the education of parents. Other significant factors include the values of education and culture in family, the search for high-quality educational institutions by parents, and their willingness to invest in children's education. Practical recommendations of the project are the support for families with pre-school and school-age children as well as individualization of the educational way of a modern person. Computer analysis is relevant to the study of large biographical arrays. The empirical prospect of the project is the ongoing analysis of various educational routes and the development of new methods of computer support for biographical research.

The reported study was funded by RFBR, project number 19-011-00947.

\section{References}

1. A.O. Kryshtanovsky, Analysis of sociological data using the SPSS package (Moscow: publishing house of State University of Higher School of Economics, 2006)

2. G. Levine, S.L. Braver, D.P. Mackinnon, M.C. Page, Levine's Guide to SPSS for Analysis of Variance, 2nd ed. (Lawrence Erlbaum Associates, 2005)

3. D.M. Rogozin, Sociological studies 10, 120 (2015)

4. S. Taylor, K. Littleton, Qualitative Sociology Review 2(1), 2 (2006)

5. My Housing History. Autobiographical essays and biographical interviews, 424 (St. Petersburg: Norma, 2018)

6. E.A. Kanevsky, G.I. Saganenko, Sociology 4M, 9, 198 (1997)

7. A.E. Geger, Sociological Studies 4, 132 (2010)

8. Z.V. Proshkova, Economics and Sociology 1(41), 21 (2019)

9. Z.V. Proshkova, G.I. Saganenko, M.N. Yashina, MTDE 2019, 694 (2019)

10. M.A. Abramova, G.S. Goncharova, V.G. Kostyuk, Sociology and Social Anthropology mg. 2, 87 (2015) 